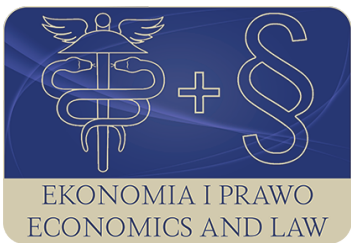

EKONOMIA I PRAWO. ECONOMICS AND LAW

Volume 17, Issue 4, December 2018

p-ISSN 1898-2255, e-ISSN 2392-1625

www.economicsandlaw.pl

ORIGINAL ARTICLE

received 02.01.2018; revised 28.05.2018; accepted 31.12.2018

Citation: Toszewska-Czerniej, W. (2018). Creating value of organization through human capital management. Ekonomia i Prawo. Ecomomics and Law, 17(4): 443-457.

doi:10.12775/EiP.2018.032.

\title{
Creating value of organization through human capital management
}

\author{
WERONIKA TOSZEWSKA-CZERNIEJ \\ Koszalin University of Technology, Faculty of Economic Sciences, Department of Management, \\ ul. Kwiatkowskiego 6e, 75-343 Koszalin, Poland \\ $\square$ wtoszewska@gmail.com
}

\begin{abstract}
Motivation: Creating competitive advantage is based on the company's ability to create value for the customer. The key factor that allows to create product or service which are compatible with the needs of customers is the employee. Held by people human capital is of particular value to the organization because of the complexity and diversity, which determines the scope of its use. Based on a model developed by J. Ingham and achievements

in the field of human capital theory in the article author attempt to develop a scheme which is allowing the improvement of human potential.

Aim: The aim of the article is to present the approach of value creation through the use of human capital. It is based on a combination of elements of the value chain and the rec-

ognition process. The presented approach gives the ability to create a human capital management strategy, which allows to determine actions that creates the level and value of processes in organization.

Results: Application of developed scheme, based on a combination of value stream with processes for human capital allows to determine the differentiation of human potential and its involvement in various organizational processes. In the longer term use of the presented approach will allow for the actual building and the development of values based on the use of organizational processes and human factor.
\end{abstract}

Keywords: human capital; human capital management; value; processes; service JEL: J24; M5; L8 


\section{Introduction}

The company's ability to obtain and maintain a competitive depends from the organizational resources. The level of competition between organizations forces them to verify the individual functions and business processes to achieve competitive advantage (Ahuja \& Kumar, 2009, p. 241). Effective transformation of input to the output that brings high value for a client is the main objective of the organization and determines the possibility of market success. Verification of the transformation process of input elements allows to show their importance for the creation of value through results. Difference between human resources determine the contribution in the process of creating the value and enable comparisons between individuals performing homogeneous processes in the organization. Service providing process is a specific one in which human capabilities and competences play a major role.

A key organization component is human capital (Król, 2015, pp. 96-98) which requires the measurement to know its true status. Therefore, choosing of appropriate methods and management techniques is required. The main aim of the article is to describe the approach of value creation through the use of human capital. The approach includes elements of the value chain and process of building service value. It helps to create a human capital management strategy, which allows to determine the appropriate action which creates the level and value of the processes.

\section{Literature review}

Human capital management is an important element of the organization's management process. People are considered as a strategic element that help to gain a competitive advantage. According to the Accounting for People Task Force 'HCM is an approach to people management that treat it as a strategic issue and seeks a systematically measure how people politics and practices create value'2, (Young, 2005, p. 24). The HRM literature explains the relationship of HRM practices and company performance through the resource-based view (Borowski, 2013; Ingham, 2007; Król, 2015). This view argues that competitive advantage is obtained when resources are valuable, rare, and inimitable. Having regard to the approach presented in the article the key organizations resource is human capital, it can be defined as the skills, knowledge, experience and health that make people economically productive (Becker, 2009; Ingham, 2007; Król, 2015). The ability to create value for the organization depends on the differentiation of the human capital components and the ability to use them. model created by J. Ingham (2007) is based on building value through the use of human capital. Literature indicates that the key to the proper use of human capital is measurement (Becker, 2009; Ingham, 2007; Król, 2015; Massingham \& Tam, 2015), the presented article uses an approach based on measuring process flow rates, in accordance with the model of creating values of M. Porter (2006). 


\section{Research approach}

In an article based on literature study's, author attempt to connect process model of the organization with elements of the human capital management process. Based on the created scheme case study was carried out, which serves as a beginning for further research process and improvement of the presented approach, in order to make better use of human capital in the organization. A case study method was employed. Presented in the article study on service process value was carried out in micro-enterprise providing services in the field of auto mechanics. The enterprise is located in the West Pomeranian province. The scope of the study takes into account the time period of six months and was analyzing the process of providing services by 6 employees. The research tool was a questionnaire of the scope of work, completed after each process, in which the employee was involved in during the working day. The verification process of creating services value by the employees proceeded according to the scheme 1.

\subsection{The process of creating value}

Creating value allows to connect the mission, goals and operational strategies, which requires the full cooperation and accountability at all management levels (Szczepankowski, 2007, pp. 19-20). Based on the presented definition is assumed, that the creation of value in the enterprise is a process that is implemented by the cooperation of three interdependent components:

- skilful connections of mission, strategic objectives and companies' tactics;

- involvement of all levels of management company;

- effective combination of quantitative and qualitative characteristics which determine the value (Nogalski \& Bors, 2000, pp. 16-21). In the process approach, the company is regarded as a process or series of related actions constituting the specified value from the customer point of view. Value chain analysis is key to understanding the strategic capabilities of an enterprise, giving a detailed look at how enterprise resources are being used, their control, and the type and quality of their interrelationships. Typically, this analysis is the cause of good or bad business condition (Weiss, 2012, pp. 261-283).

Current research emphasizes the usefulness of organizational outcomes to others when defining value (van Fenema et al., 2014, p. 180). Theoretical analysis of the concept of value, presented in the literature, focuses on examining the influence and strength of the structure of the sources of value creation and the evolution of the relationship between them. At the strategic level of organization, the value method has a role in the design of programs intended to deliver strategic benefits (Jay \& Bowen, 2015, p. 132). Analyze of the value process enabled to form a sequential approach to value creation. Value stages are created based on the division of the processes, they have the ability to in- 
form the organization and the client on the state desired, and the level of obtaining this status. The formula value management is therefore a concept that unites the customer value theory with value for the owner's approach. M. Porter (2006, p. 22), says that this concept allows a systematic look at the source of the value generated for the buyer. The selected stages of value generation take into account the three phases in which the value of the input and output flows are generated by the actions to which they are subjected. The elements of the process are shown in scheme 2 .

In the various phases it is important to isolate a sub-action and action that create value for the customer. It is important to define the key areas of activity of the company sources of competitive advantage. Extracting measures of value or combining them is done in terms of their impact on competitiveness (Borowski, 2013, p. 16).

\subsection{Creating processes value by human capital}

There is recent interest in other capitals and how these can be used to create organizational value (Massingham \& Tam, 2015, p. 399). According to the theory, there are three ways of recognition, intangible and tangible assets that allow to provide value in strategy. Each affects the functioning of the company and generate financial results in different extent. The first stage is the level of value creation that represents a matching individual skills to organizational capabilities. This is the basis to achieve the organization's return in investment, which will exceed the cost of capital invested. A key element from the point of view of the theory of human capital is the ability to assembly workers with high level potential of uniqueness in generated processes.

The second area is primarily focused on internal processes, carried out by employees. Depending from the level of the contribution action taken in the second area are the basics for obtaining the desired effects. The final step in process of value making is formed value, characterized by having a corresponding increase in potential relative to the input. Important role plays the measurement process, which is the primary method for verifying effectiveness of the HR processes. Scheme 3 takes into account the different phases of the value creation process which determinate the process of generating the value.

Recognition of activities relating to the implementation of the HR function on the basis of the process approach is based on a concept created by J. Ingham (2007). It allows to share value creation in three basic stages, on actions in the field of human capital management.

The first stage is value for money, defined as the value of the contribution. This area refers to the basic elements of value, primarily material, which can create increased efficiency. It also considerate the legal requirements and other basic standards. It is a useful area that not always allow to achieve business objectives and ensure customer satisfaction. It has however a direct impact on financial results. 
The second phase of the added value represents the necessary skills to meet business needs. These activities may affect a significant improvement in the efficiency of the processes, but above all, is increasing the efficiency leading to growth, change and development of organizational processes.

The last stage produced value represents the result of undertaken activities. The principle of this area is that continuous improvement generated value is insufficient. Skills and abilities to create value are required to be able to surprise competitors and change the nature of the areas of competition.

Just as in the assumptions of the resource theory created intangibles assets must be valuable, rare, durable over time and not easy to follow. The generated value consistent with the assumptions may be difficult to develop and even more difficult to maintain. The pace of change in the economy with an increase in competitive activity may mean that resources and skills can move to a lower level values. This usually means that what the present moment is generated value can, in a short period of time, constitute an initial value, which is the foundation subjected to actions aimed at producing value growth.

The approach focused on the application of methods and techniques which are tailored to the accumulated capacity has led to the development of intangible assets, but if they are not in line with the business strategy of the company will not be able to generate added value. Step output includes both tangible and intangible outputs of processes. Tangible outputs refer to the number of employees, their observable behaviour, explicit knowledge and skills. The outputs of intangible assets related to the formation of human capital, organizational and relationship include human capabilities, commitment (Hamel \& Prahalad, 1994, p. 163).

Every element in the chain requires the development of an individual set of measures, adequate to the ongoing practices. Consistent measures of value should be developed for each area of consideration, taking into account the different approach to specific areas of the strategy. Thus, it is assumed that the activity value through the implementation of more than one process. In addition, different levels of human capital management enable the development of activities in support of the various elements of the human resources strategy (Ingham, 2007, p. 183).

Process approach shows how the human factor contributes to the creation of value and is a basic assumption of the presented concepts. Employees with possessed potential play a special role in the process of creating services value. To a large extent, the employees determine the effects of the process of service. Individualized nature of services due to primarily from the relationship between the contractor and the result. Using the presented scheme based on the input and output streams may be characterized the service providing process. 


\subsection{Service delivery process}

Effects of the business operations of the production system can be interpreted as resource efficiency input system - human labour, capital, materials in the production of goods and services that represent its output (Piętowska-Laska, 2008, p. 83). As the service is determined every action contains an element of immateriality, which consists in influencing the customer or items or properties that are in his possession, and that does not transfer ownership rights (Payne, 1997, p. 9).

Services have been characterized differently to goods and are said to be defined by their intangibility, inseparability and simultaneous production, distribution, and consumption (Resnick et al., 2014, p. 840). Regardless of the type of services there is a similar increase in the impact on consumers of different social, economic and technological. Among the forces bearing the growth in consumption of services are included: increasing the level of income per capita, the need for a wider range of social benefits, the size and role of the public sector, the complexity of working environments, increased specialization, relaxation of trade barriers. These trends contribute globally to the increasing importance of service processes (Bryson et al., 2004, p. 243).

In the process of value creation companies use the specific contribution that through the process of transformation creates a service that allows to meet the needs of customers. In addition, service staff ought to offer not only professional and competent but also personal and friendly service with a proactive approach to customer needs (Ilicic \& Webster, 2015, p. 174). Construction of values requires multiple integrated steps in many areas of business (Jeziorski $\&$ Borkowski, 2008, p. 38). The effectiveness of this process depends on the resources available and the capacities that have units operating in organization structure. Scheme 4 shows the elements building the process of service.

Resources are identified with the contribution necessary to provide services. The diagram takes into account the area of infrastructure, information, agents and employees as key elements of the input process. While ability is understood as corporate know-how in the field of coordination, control and deployment of resources of value in certain parts of the organization. The task of the specific ability is to provide enterprise possibilities for optimal use of resources in the process of creating value for customers.

According to the approach presented in the article key importance in provision of services is attributed to employees. The only elements belonging to both the ability and resources. This underlines the primacy of employees in the process. The ability of employees is identified with potential, which accumulated in the employees, allows for the implementation of the process of providing services in a way that ensures the achievement of customer satisfaction. People are a very important factor differentiating services. By creating additional benefits become a source of competitive advantage (Michalski, 2007, p. 535). 


\section{Methods}

The analysis made in the study was based on the verification of a service process implemented by 6 employees of the company. Participants in the study taking into account the age and work experience have been apprehended on five charts. Each of the employees for a period of six months, that defined the case study period, has generated an output value with the involvement of appropriate value contribution.

Chart 1 shows that the staff of the company is young, since the average age is 31.4 years, and the average seniority in the company is 5.6 years. This situation has both positive and negative aspects affecting the organization's activities. Employees are characterized by a fresh approach, low probability of professional burnout, lack of generational differences. However, there are limitations related to the low level of experience, which is extremely important in the process of providing services and which affects the number of mistakes made by employees during their work.

The duration of the study lasts a period of 6 months. The article included the results of studies taken from March to August 2016. Tested processes consider the position of employees recurring tasks, including repair and replacement of parts of motor vehicles and motorcycles.

\section{Analysis of value creation process}

High value of the human factor is one of the conditions for the development of enterprises, as conducive to lowering the costs of their activities, thereby increasing their competitiveness. Value calculations in presented study were based on the contribution of the companies on the value of expenditures used in the service process and the value of employee engagement defined by the company as $25 \%$ of the hourly work of the employee. The output value is built by the value of services produced, as reflected in the amount of what the customer pays. The approach to the calculation was conditioned by an arrangement with the company, which established minimum interference in the process of work and limited access to financial data.

An analysis of creating value requires the presentation of input amount that the particular process involved. According to the presented in scheme 4, it is necessary to present the value of assets and capabilities, which are the basis for building the value of service processes. Chart 2 shows the differences in the value of work in PLN and the resources used by employees in the considered period, which are considered as an input in the service providing process.

The figure shows the disparities existing between the values of the inputs by individual employees. In all cases there is a visible increase in the value input in the second quarter survey. This is mainly due to the increase in the amount of processes, partly as a result of the dismissal of two workers. After each service employee on specially designed for testing sheet marked the working time 
and the type of used labour resources involved in the service process. In the following part of the study on the basis of demonstrated value the size of transformation and output value of individual employees will be presented.

The transformation is generally defined as a kind of process changing the subject, consisting of its converting by mechanisms of natural or put into action by the people (Wróblewski, 2009, p. 9). Organizational processes in order to enable the generation of value for the customer include all the costs of the resources involved directly and indirectly in the process. In the study included only the cost of the work of the employee, as factors determining the value of engaging human capital. This is a great simplification and requires further work on the application of the concept of enlargement and the fulfilment of other variables. Chart 3 shows how during the individual months has changed the value of the transformation processes created directly by employees.

The value of work in the considered case takes into account that part of the salary, which is built on the basis of the unit cost of work time for each employee determined in the examined company. Recognition of remuneration from the point of view of the employer recognizes them as the purchase price of a factor representing the manufacturing component of total production costs. Considered from the point of view of the employee is the income arising from the involvement of their own capital on the basis of the employment relationship. An efficient system of remuneration should have been designed so as to provide an opportunity to develop both the level of competitiveness of the company and the competence of the worker (Borkowska, 2004, p. 11).

The result of the involvement of human capital is the effect in the form of services delivered to the customer. From the point of view of the present concept value of outputs reflects the difference between the value of time and the level of remuneration obtained by the employee. Such a distinction allows to evaluate the actual value of the output stream generated through the involvement of employee human capital. Chart 4 shows the output values of employees of the company.

Considering that human capital management process allows for more accurate separation of the actual values built up through commitment of human capital in various organizational processes. In the present case, which included a comparison of the same processes carried out by employees working in the same conditions for the same period of time verification streams does not constitute such a complex task. The following figure shows the disparity between the values input, transformation and output produced by individual employees.

Chart 5 shows that in described example the value of outputs in every case is higher than the input element. This only proves the validity of the basic assumptions of the process model. Human capital management should mainly help to build value by the human factor. Demonstrated by testing disparity proves the validity of the basic assumptions of process approach. However, given that the knowledge of the true value of what is created by people in the or- 
ganization requires meticulous verification of the contribution of each employee in the stream and separate the contributions provided by the organization is necessary to deepen the scope of the study.

The next stage of the presented approach should be verification of the reasons for the disparities, which primarily requires a detailed measurement of human capital. An important challenge for human capital research is to identify a set of measures which are widely accepted and adopted. The field's focus on measurement appears to suggest that it must be accurate before progressing to managing (Massingham \& Tam, 2015, p. 393). This measurement should cover the elements involved in the production of services such as capabilities, competences, satisfaction and involvement. Employee satisfaction and commitment refer to the individual's emotional relationship with the organization and help understand whether they will use their knowledge to create value for the firm (Massingham \& Tam, 2015, p. 395).

\section{Conclusion}

Included in the article approach assume that generate value by human capital is the basic factor of the success of the organization. The value of their contribution to the value of creation process is determined by the level of investment. The technical capabilities and intellectual potential of the employee help to see that the process is not just an executive standard. Processes are to be the point of reference for executives, in order to indicate the direction of activities that will be optimal for fulfilling customer expectations (Kisiel, 2015, p. 89).

The purpose of the use and development of human capital is to maximize its value during the implementation of management processes. Shaping the service process is determined by the strength of mind and the ability of its use by employees. Inclusion in the human capital management process of the value chain has allowed it to identify disproportions in the contribution of individual workers in streams of value. This is an easy way to understand how important is the human potential involved in specific organizational processes. This is first and foremost an impulse to investigate the reasons for creating services of varying levels of value.

\section{References}

Ahuja, I.P.S., \& Kumar, P. (2009). A case study of total productive maintenance implementation at precision tube mills. Journal of Quality in Maintenance Engineering, 15(3). doi:10.1108/13552510910983198.

Becker, G.S. (2009). Human capital: a theoretical and empirical analysis, with special reference to education. Chicago-London: University of Chicago Press.

Borkowska, S. (2004). Wstęp. In S. Borkowska (Ed.), Wynagrodzenia - rozwiązywanie problemów w praktyce. Kraków: Oficyna Ekonomiczna. 
Borowski, J. (2013). Łańcuch wartości jako nowa teoria zarządzania strategicznego. Optimum. Studia Ekonomiczne, 2(62).

Bryson, J.R., Daniels, P.W., \& Warf, B. (2004). Service worlds: people, organisations, technologies. New York-London: Routledge.

Hamel, G., \& Prahalad, C.K. (1994). Competing for the future. Harvard: Harvard Business School Pres.

Ilicic, J., \& Webster, C.M. (2015). Consumer values of corporate and celebrity brand associations. Qualitative Market Research: An International Journal, 18(2). doi:10.1108/QMR-06-2013-0037.

Ingham, J. (2007). Strategic human capital management creating value through people. Amsterdam: Elsevier.

Jay, C.I., \& Bowen, P.A. (2015). Value management and innovation: a historical perspective and review of the evidence. Journal of Engineering, Design and Technology, 13(1). doi:10.1108/JEDT-03-2013-0021.

Jeziorski, L., \& Borkowski, S. (Ed.) (2008). Zarządzanie, doskonalenie, zmiany. Sosnowiec: Humanitas.

Kisiel, A. (2015). Zarządzanie wiedzą a dojrzałość procesowa. In D. Jelonek \& T. Turek (Eds.), Kreowanie przedsiębiorczości. Perspektywa procesów i technologii informacyjnych. Częstochowa: Politechnika Częstochowska.

Król, H. (2015). Kapitał ludzki organizacji. In H. Król \& A. Ludwiczyński (Eds.), Zarządzanie zasobami ludzkimi. Tworzenie kapitatu ludzkiego organizacji. Warszawa: PWN.

Massingham, P.R., \& Tam, L. (2015). The relationship between human capital, value creation and employee reward. Journal of Intellectual Capital, 16(2). doi:10.1108/JIC-06-2014-0075.

Michalski, E. (2007). Marketing. Podręcznik akademicki. Warszawa: PWN.

Nogalski, B. \& Bors, K. (2000). Zarządzanie przez wartość. Przegląd Organizacji, 4 .

Payne, A. (1997). Marketing ustug. Warszawa: PWN.

Piętowska-Laska, R. (2008). Procesy wzrostu produktywności pracy w firmie na przykładzie branży budowlanej. In M.S. Kostka, \& D. Ostrowska (Eds.), Ekonomiczne uwarunkowania rozwoju spoteczno-gospodarczego w skali lokalnej. Białystok: Wyższa Szkoła Finansów i Zarządzania w Białymstoku.

Porter, M. (2006). Przewaga konkurencyjna. Gliwice: Helion.

Resnick, S., Foster, C., \& Woodall, T. (2014). Exploring the UK high street retail experience: is the service encounter still valued? International Journal of Retail \& Distribution Management, 42(9). doi:10.1108/IJRDM-05-2013-0090.

Szczepankowski, P. (2007). Wycena i zarządzanie wartością przedsiębiorstwa. Warszawa: PWN.

van Fenema, P.C., Keers, B., \& Zijm, H. (2014). Interorganizational shared services: creating value across organizational boundaries. In T. Bondarouk (Ed.), Shared services as a new organizational form. Bingley: Emerald Group Publishing Limited. doi:10.1108/S1877-636120140000013009. 
Weiss, E. (2012). Instrumenty podejścia procesowego w zarządzaniu przedsiębiorstwem. Zeszyty Naukowe Uniwersytetu Szczecinskiego. Finanse, Rynki Finansowe, Ubezpieczenia, 56.

Wróblewski, R. (2009). Teoretyczne problemy transformacji przedsiębiorstwa. Zeszyty Naukowe Uniwersytetu Przyrodniczo-Humanistycznego w Siedlcach Seria: Administracja i Zarządzanie, 83.

Young, S. (2005). 10 steps to successful human capital management. Strategic HR Review, 5(1). doi:10.1108/14754390580000848.

\section{Acknowledgements}

Author contributions: author has given an approval to the final version of the article.

Funding: this research was undertaken as part of The paradigm of organization management, stage III project and was fully funded by a grant 504.04.08.

Note: the results of this study were presented at 9th International Conference on Applied Economics Contemporary Issues in Economy (June 22-23, Toruń, Poland). 


\section{Appendix}

Chart 1.

Survey respondents

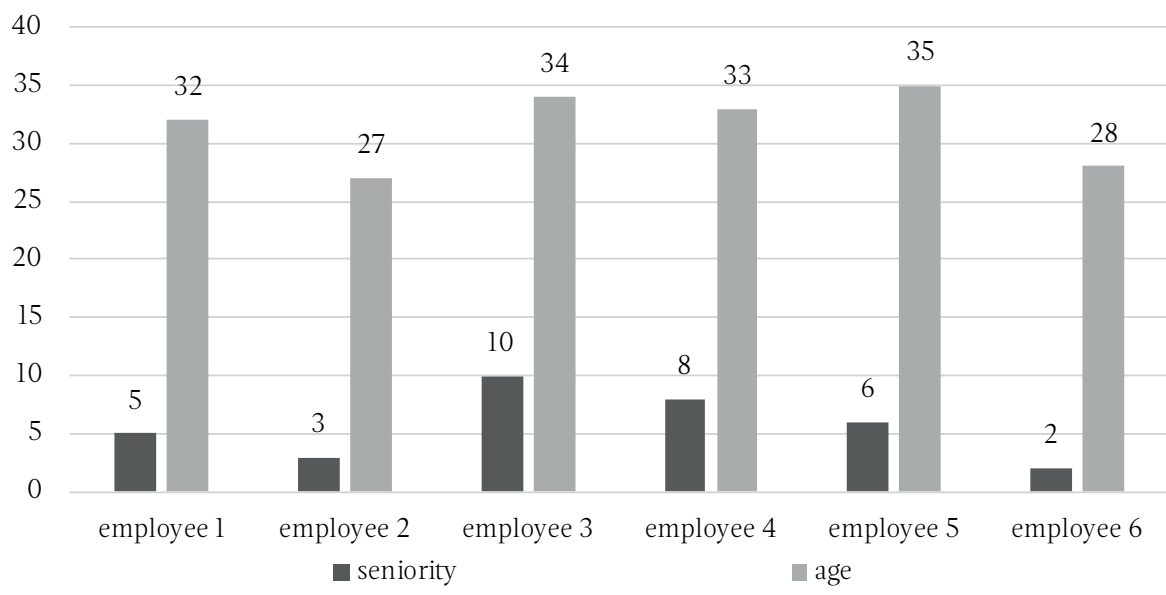

Source: Own preparation.

\section{Chart 2.}

Levels of input streams

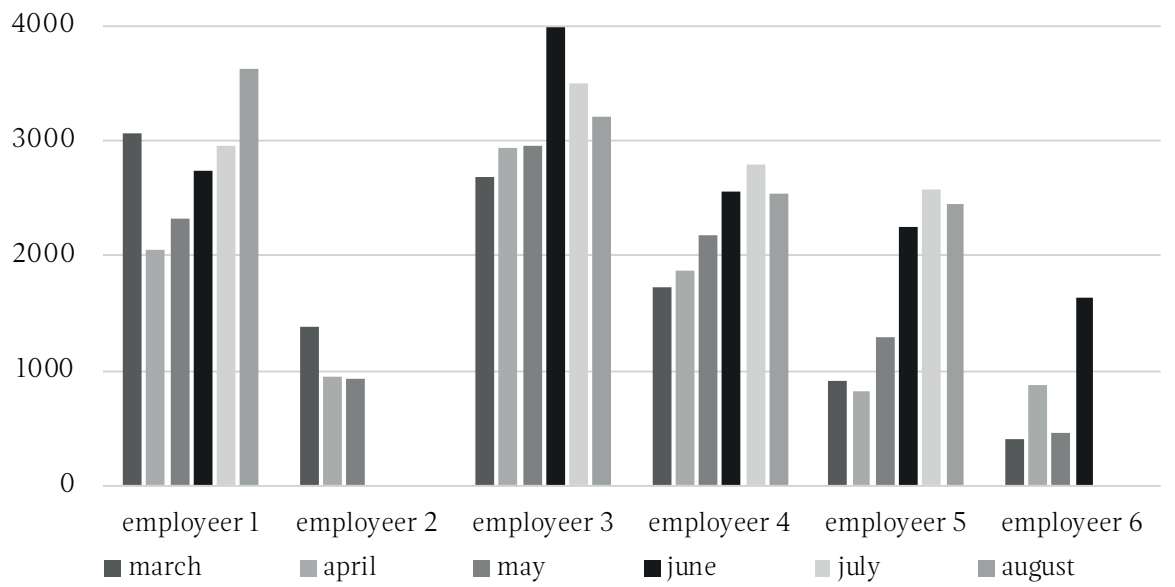

Source: Own preparation. 


\section{Chart 3.}

Levels of transformation

10000

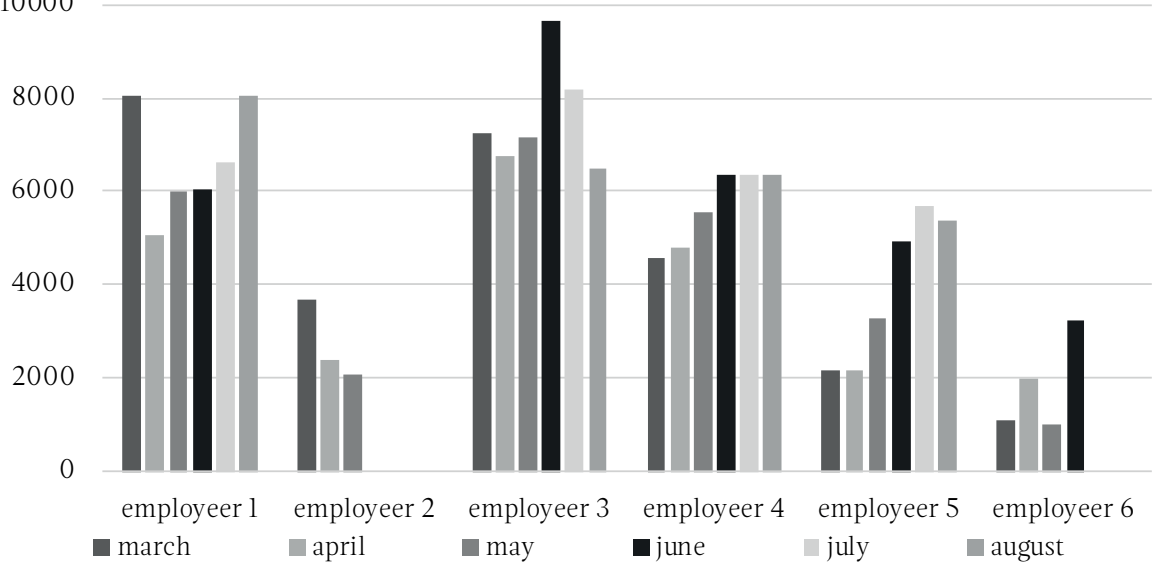

Source: Own preparation.

\section{Chart 4.}

Levels of output streams

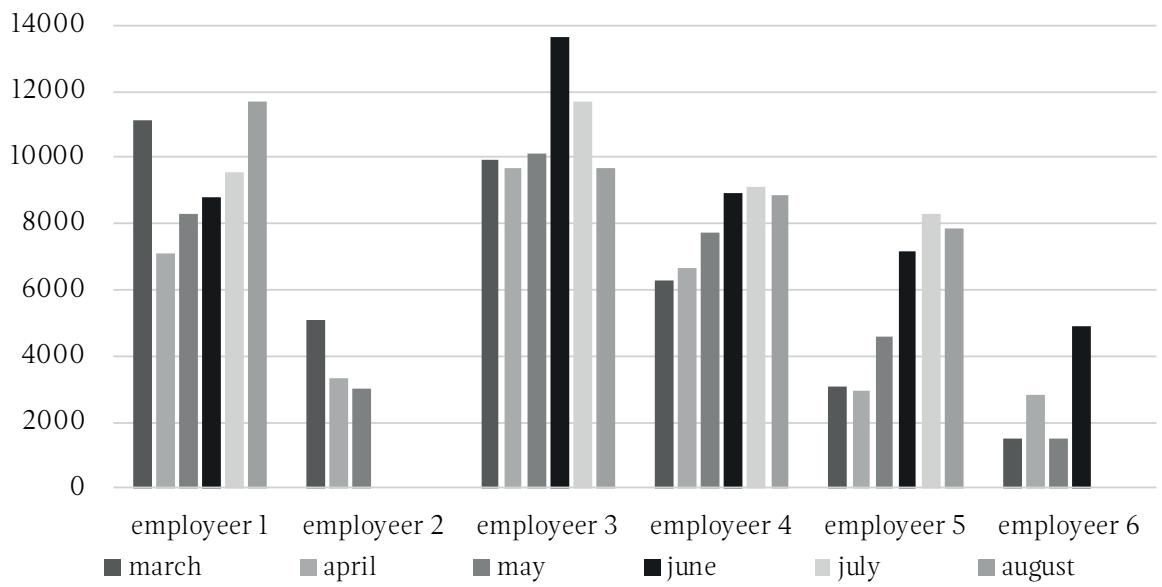

Source: Own preparation. 


\section{Chart 5.}

The levels of value created by employees

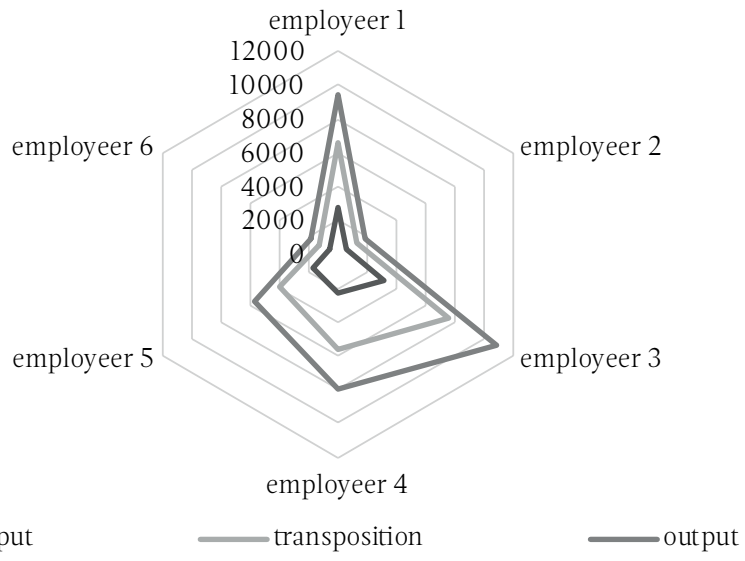

Source: Own preparation.

\section{Scheme 1 .}

\section{The process of obtaining data}

assigning an employee to the service

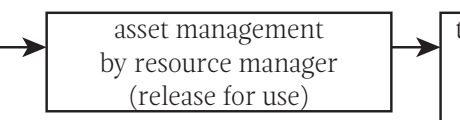

the process of transforming the collected elements and the employee's own contribution into the result (transformation)

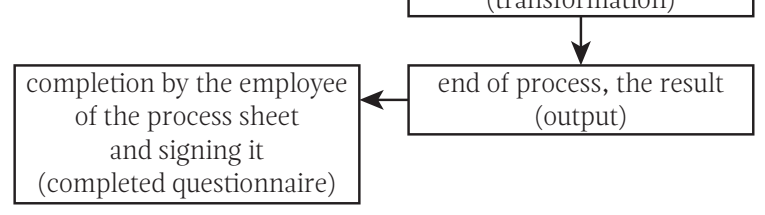

Source: Own preparation.

\section{Scheme 2.}

\section{Elements of the process approach}

\begin{tabular}{|c|c|c|}
\hline creating value & $\begin{array}{c}\text { maintenance } \\
\text { and development of value }\end{array}$ & generated value \\
\hline $\begin{array}{l}\text { use of resources acquired } \\
\text { from the environment }\end{array}$ & $\begin{array}{l}\text { processes implemented } \\
\text { that allows to build } \\
\text { customer value }\end{array}$ & $\begin{array}{c}\text { process results } \\
\text { that are characterized } \\
\text { by value for the customer }\end{array}$ \\
\hline
\end{tabular}

Source: Own preparation based on Porter (2006). 
Scheme 3.

Elements of value creating process

\begin{tabular}{|c|c|c|}
\hline creating value & $\begin{array}{c}\text { maintenance } \\
\text { and development of value }\end{array}$ & generated value \\
\hline $\begin{array}{c}\text { contribution, conditioned } \\
\text { by human potential }\end{array}$ & $\begin{array}{c}\text { processes implemented } \\
\text { under the build customer } \\
\text { value and personnel strategy }\end{array}$ & $\begin{array}{l}\text { the effects conditioning } \\
\text { the effectiveness of the } \\
\text { practices that build value }\end{array}$ \\
\hline
\end{tabular}

Source: Own preparation based on Ingham (2007).

\section{Scheme 4.}

Structure of the service process

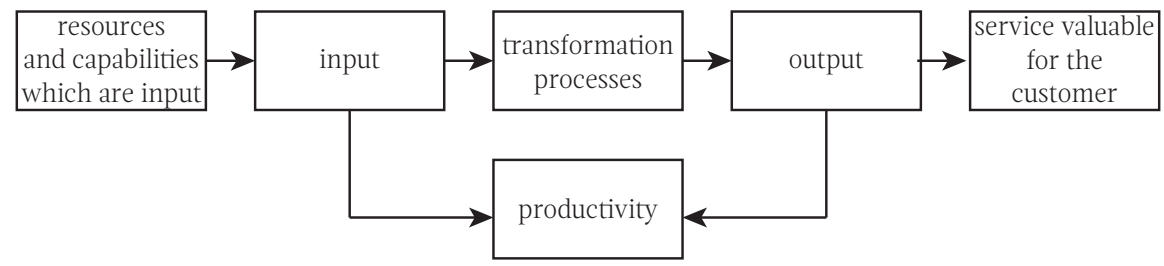

Source: Own preparation. 
